\title{
On the Role of Internal Audit in Corporate Governance
}

\author{
Jianjun Zou \\ Guangdong Polytechnic of Industry and Commerce, Guangzhou, China \\ Email: 15989056266@163.com
}

How to cite this paper: Zou, J.J. (2019) On the Role of Internal Audit in Corporate Governance. American Journal of Industrial and Business Management, 9, 63-71. https://doi.org/10.4236/ajibm.2019.91005

Received: December 14, 2018

Accepted: January 7, 2019

Published: January 10, 2019

Copyright $\odot 2019$ by author(s) and Scientific Research Publishing Inc. This work is licensed under the Creative Commons Attribution International License (CC BY 4.0).

http://creativecommons.org/licenses/by/4.0/

\begin{abstract}
As the economy develops faster and faster, the role of internal audit in the company becomes more and more important, especially for corporate governance. The trend of globalization has intensified, and trade between countries is dense. It brings economic benefits to enterprises while increasing risks. In order to survive and develop, companies must face more challenges. On the one hand, the company must increase investment in internal governance management, and establish institutions such as shareholder meeting, board of directors, managerial level and board of supervisors, and the corporate governance structure is gradually standardized. On the other hand, the company's strengthening of internal audit can not only improve the company's operating conditions, but also timely discover problems within the company and effectively control them. However, compared with other advanced countries in China, the internal audit system was established late, so the units have different experiences in learning from foreign countries, which leads to many problems in the establishment of internal audit institutions in China, and many companies do not pay attention to internal audit. Therefore, it is necessary for us to conduct in-depth research on this.
\end{abstract}

\section{Keywords}

Internal Audit, Corporate Governance

\section{Introduction}

Under the trend of global economic convergence and changing market environment, there are inevitably large changes in the practice of corporate governance in various countries, which makes more and more company owners and leaders realize that corporate governance is Strengthening core competitiveness and increasing the company's performance plays an important role in realizing 
that good governance can protect investors and stakeholders from all walks of life and ensure that the modern market economy system can operate healthily and steadily. At present, internal auditing abroad has successfully participated in corporate governance as an indispensable part of corporate governance structure and plays a pivotal role. In China, internal auditing is gradually practiced in the corporate governance structure and its status and role are not short. However, in recent years, China's market economy has frequently disclosed cases of ineffective internal control, unsatisfactory business performance, unreliable financial information disclosure, and even high-level personnel collaborating in fraud cases. One of the reasons is that internal audit has not been effectively implemented its role in corporate governance. How to improve the internal audit of Chinese companies, which can better help corporate governance, has attracted the collective attention of experts in the auditing and practical circles in China. Therefore, it is of great practical significance to explore the specific role of internal audit in corporate governance in China and to continuously promote the effective play of these roles.

\section{Overview of Internal Audit and Corporate Governance}

In recent years, fraud cases of companies from all over the world have been exposed. The traditional auditing and board of directors have failed to play their supervisory role. People began to shift their focus to internal governance. Since then, internal audit has been on the stage of the world and has received more attention and attention.

1) Overview of internal audit

According to the "Internal Audit Practice Framework Standard" launched by China in 2011, internal audit is an activity with both independence and objectivity. Its main work is confirmation and consultation [1]. Internal audit selects a scientific and rational approach to evaluate the effectiveness of risk management efforts to ensure that organizations achieve development goals faster and better. The fundamental purpose of a company is to make profits and maximize its value. In the whole process of operation, there will always be various problems, and the existence of these problems will greatly hinder the healthy development of the company. Internal audit activities exist to solve these problems. It makes full use of appropriate auditing methods, reveals the shortcomings in the process of comprehensively and objectively reflecting the implementation results of the enterprise system, and proposes targeted solutions. The department's work is improved, which promotes the company's sustainable development towards the goal, while effectively monitoring the company's property, reducing unnecessary expenses, and ensuring the security of the company's resources and property.

According to the theory of the Institute of Internal Auditors, the internal audit work is organized to promote the improvement of its own value, so the function of this work is to confirm and consult.

2) Overview of corporate governance 
In essence, the purpose of corporate governance is to save on the agency costs of modern enterprises that implement the "two-right separation" system. The company combines its own actual situation and relevant legal requirements to formulate a sound and modern rules and regulations system, and distribute the rights, responsibilities and interests of personnel in different roles within the enterprise to ensure that its shareholders, board of directors and senior executives can check each other. Driven by the development of the times, the benefits of the company no longer only affect the interests of shareholders, the company has become a whole benefit including employees, customers, suppliers, and its benefits will affect the interests of the various members of the whole. The company adopts scientific management methods, continuously cooperates, promotes the realization of goals, and provides protection for the interests of all stakeholders.

Corporate governance is a discipline that was born under the impetus of the continuous development of Western companies. In the 1870s, the idea of "separation of the two powers" did not appear. After entering the 1920s, the scale of the company expanded rapidly, and the owners distributed the important tasks of the business to the managers. Back in the 70s, the control of the operators was getting bigger and bigger, and the issue of corporate governance caught people's attention [2]. Nowadays, the contradiction between owners and operators is becoming more and more fierce. We have to deeply reflect on corporate governance in China.

\section{The Analysis of the Relationship between Internal Audit and Corporate Governance}

China's internal audit development has not been long, but it has achieved remarkable achievements, but there are still many loopholes. Especially in the rapid development of the modern corporate system, the role of corporate governance has become particularly important. These stakeholders will require their corresponding rights in the company structure. A sound governance requires checks and balances of various factors, while internal audit It plays an important role.

1) Internal audit is an integral part of corporate governance

The board of directors, executive management, external audit, and internal audit basically determine the integrity and security of the corporate governance structure. A company's healthy development is inseparable from a solid governance structure. Boards and senior management need to fully understand the various factors and risks that threaten the achievement of the goals. In the process of executing the target, various performance situations may have deviations that affect the achievement of the target. At this point, an independent role is needed to monitor operations, and internal audit can play such a role. Through various review methods, timely evaluation can reflect various risks and existing problems in internal operations, report to management in a timely manner, issue revised plans, and implement revised plans to ensure the final goal 
is achieved. Therefore, when using internal audit to evaluate the implementation results of the enterprise system, its focus is mainly on whether the corporate governance structure has achieved effective checks and balances. Thus, in the field of corporate governance, internal audit plays an irreplaceable role.

2) The role of internal audit in promoting the corporate governance structure of corporate companies

In advanced foreign companies, in order to better manage the company, they all attach great importance to internal audit, which shows that the company's sustainable development is inseparable from internal audit. Internal audit plays a facilitating role in corporate governance structure, mainly in the following two aspects:

a) Internal audit is an important means to promote effective corporate governance

Under the modern company system, "the rights and responsibilities are clear, and the government and enterprises are separated." Shareholders have a lack of understanding of the company's operations and there is a possibility of decision-making risks: while management attaches importance to operational risks and prevents losses, it may ignore internal regulatory risks and Audit risk: For potential investors, the company's comprehensive development capabilities and operating performance are more fancy. Internal audit has found a way to solve these problems. Through independent and objective review, it can evaluate the company's operating conditions and effectively supervise the company's resources. Compared with external auditing, it is more familiar with the status quo of the enterprise, and can provide professional and objective audit evaluation for the demander, so as to make more accurate decisions.

b) Internal audit and corporate governance have a common purpose

Enterprises are profit-seeking organizations, and the effectiveness of corporate governance is related to the degree of coordination of the rights of various rights holders. Corporate governance is to achieve a good balance between this relationship, thus providing a guarantee for the continued growth of the company's economic interests [3]. As an independent and objective existence within the enterprise, internal audit can effectively supervise the operation of the company without being bound, and truly reflect the problems of the enterprise, thus helping the company to improve operational efficiency and promote the growth of economic interests. Therefore, internal audit and corporate governance The purpose coincides.

3) The impact of corporate governance on the internal audit environment

On the one hand, corporate governance can enhance the independence and authority of internal audit. In the fierce battle of the economy, only the cooperation of internal auditing continuously enhances the company's profitability is the key to stand out, and when an operator ignores the problems in the company. When it happens, it will lead to business failure. To ensure the authority of internal audit, companies should create conditions for independent work for the 
audit department. In addition, the objectives to be achieved by internal audit are related to corporate governance. It differs from the government's regulations on this work, because internal audit is an assisting department within the company.

\section{The Problems in the Process of Modern Corporate Governance}

With the acceleration of economic globalization, many Chinese companies are listed in the US, many Chinese companies have been investigated and punished by regulatory agencies, class actions, delisting, etc. These series of negative news have seriously affected the image of Chinese companies in the international market.

1) The internal audit of modern companies is not perfect and the degree of emphasis is not high

China's internal audit development is lagging behind other advanced countries' enterprises. Auditors do not have enough experience or technology to develop and improve internal auditing. They are all modified and used in foreign control tests. In particular, some of the specific audit procedures have not been specially developed, and the audit guidance is only framework, and can not meet the characteristics of various types of companies for effective auditing, and put forward practical recommendations. The general internal audit is based on the principle of voluntariness. The setting of internal audit depends on whether the company has the necessary settings and the amount of audit work. But most of the current companies are forced to set up because of government pressure, not out of consciousness. As a company's top management, a company's operators, they tend to focus more on how to improve economic efficiency, streamline the structure of the company's department, are unwilling to recruit high-quality professional auditors, and China's current legal system. It is not suggested that enterprises must establish an internal audit department. The existence of these objective reasons has made internal audit work a neglected awkward situation for a long time.

\section{2) The independence of internal audit has not been fully utilized}

The main feature of internal audit is independence. If this is not fully guaranteed, internal audit work will be difficult to achieve the desired results. According to the relevant provisions of the Company Law, the internal audit department is managed by an audit committee attached to the board of directors. In order to reduce various costs such as human resources, many companies require financial personnel to be audited, or the general manager to lead the audit department [4].

In fact, this kind of setting makes the audit department easy to be pressured by the top management, cannot play the independence of the audit, cannot effectively prevent financial fraud and effective monitoring of senior managers. For example, the $\mathrm{CAO}$ incident, although they have their own internal audit, but they have not received the attention of management, they are in vain. As a result, 
the internal audit status is low, the supervision authority is very limited, and the independence of the audit is greatly reduced. Therefore, it is difficult to achieve the expected effect and become a security risk of enterprise development.

3) The quality of auditors is low and audit technology is backward

In the domestic internal audit field, there is a serious imbalance between supply and demand in professional talent resources. The overall quality of the existing auditors is not high, mainly reflected in these aspects: the auditors did not receive professional knowledge and skills training, the professional knowledge is not rich enough, most of the auditors are transferred from the financial staff, it is difficult to meet the audit work. The need for economic management knowledge. In addition, internal auditors have low levels of professional ethics and are difficult to adhere to in the course of their work. Auditing can act as a deterrent to fraud and expose fraud that has already occurred. The low professional ethics of internal auditors indicates that corporate governance is low. For example, the Andersen Incident, in order to retain this large customer, and obtain considerable audit fees, turned a blind eye to the unreasonable accounting treatment in the audit, did not adhere to the application of professional prudence and suspicion, did not find the existence of financial fraud, and ultimately led to audit failure. The internal audit staff must improve their quality and professional skills in order to successfully complete the audit task.

In addition to the quality of personnel, the backwardness of auditing technology is also a very important factor. The rapid development of modern network communication technology has led to the development of internal audit. However, China's internal audit technology and methods are still very backward compared with foreign advanced companies. After-the-fact audit, static audit, these backward audit methods not only did not achieve the expected results, but also spent more time, resources and other resources.

\section{Explore Ways to Strengthen Internal Audit and Improve Corporate Governance}

The improvement of the company's internal audit is conducive to preventing the fraud of senior management personnel and protecting the interests of shareholders and investors; it is conducive to timely grasping the problems existing within the company and promptly correcting and improving the operational efficiency of the enterprise; it is conducive to safeguarding the property security of enterprises and enhancing the value of enterprises. There are still many shortcomings and imperfections in China's internal audit. Strengthening the exploration of internal audit is the way to promote the healthy development of Chinese companies.

1) Improve the company's internal audit system to promote the sustainable development of enterprises

Government audits and internal audits complement each other and play an indispensable role in China's audit system. Although China is not as perfect as 
the development of foreign internal audit, it can learn from foreign advanced experience, learn from foreign advanced auditing techniques and combine specific national conditions, and explore and explore an internal auditing road that belongs to us. With the aid of computers and the Internet, the establishment of data models, the reduction of audit workload, and the improvement of work efficiency, etc., we need to continuously absorb and mine our audit through our own exploration efforts. In addition, in addition to economic supervision, government audit institutions should also supervise and guide the audit activities of the company's internal audit, and actively guide their work to become more standardized and professional. In addition, it is also important to improve the auditing law. It can make the company's internal audit work more organized, legally compliant, and create a good environment. Form a collaborative mechanism for internal and external audits, reduce the pressure on audit work, promote the improvement of audit efficiency, and eliminate hidden dangers of fraud. The joint development of internal audit and company audit has a positive significance for improving the macro audit system and helps to promote long-term stable and healthy development.

\section{2) Give full play to the independence of internal audit}

To fully play the role of internal audit, we must grasp the core "independence" of internal audit. The company must improve the company's rules and regulations, and use the system charter to give internal audit sufficient rights. In state-owned enterprises, there are often times when shareholders can absolutely control the operation of the company, or the uneven distribution of rights leads to the imbalance of the company structure, and the power is excessively concentrated in the hands of insiders, which seriously affects the development of the audit work. Therefore, it is necessary to improve the company's rules and regulations, improve internal auditing, implement job rotation, and reduce collusion. At the same time, senior management personnel must have sufficient support for internal auditing, arrange arrangements according to the company's development requirements, and give internal audit a good operating environment. Cooperate with external audit to promote the overall improvement of audit quality. The implementation of the above measures is very helpful for strengthening the internal audit effectiveness, thereby further promoting the improvement of corporate value and effectively solving the problem of poor corporate management or government auditing.

\section{3) Improve the quality and professional skills of internal auditors}

In August 2001, the "Yinguangxia" incident was exposed by the media. The auditors did not understand the foreign trade business, and did not have professional auditing techniques and implemented effective audit procedures, which led to a major impact on society [5]. This reflects a common phenomenon in our country, that is, the lack of professional knowledge and skills of our auditing practitioners, because most of them are directly separated from the financial profession, and there is no professional training through auditing. Therefore, the company is sifting, and internal auditors must be rigorous. At the time of re- 
cruitment, you can conduct multiple assessments and retests. Be sure to select the people who understand the audit knowledge. Integrity of professional ethics cannot be ignored, the primary professional ethics of internal auditors is integrity. In the process of carrying out related work, internal auditors must follow objective principles, adhere to the bottom line of professional ethics, and continuously improve the efficiency of audit work. In addition, it has the spirit of study hard, and spends time in the spare time to explore deeper professional knowledge and improve the comprehensive ability of its own audit.

Internal auditors should also broaden their knowledge while receiving professional skills training. They should understand the aspects of business management, facilitate and conduct audit activities more effectively, learn advanced foreign audit methods, conduct full-time audits of work, and combine audits. The method replaces the backward audit method and improves the audit efficiency. After the post, the internal auditor's technology can be further expanded, and they are encouraged to use the Internet and computing to learn about business knowledge in other fields and obtain relevant certificates.

\section{Conclusions}

Internal audit can not only maintain the balance between shareholders and senior management in the company, ensure the correct performance of fiduciary responsibility, but also help the correct disclosure of financial accounting information, protect the legitimate interests of stakeholders, and help the management and scientific decision-making of enterprises have a positive effect on the improvement of corporate value. Internal audit and corporate governance complement each other and are inseparable. Corporate governance is the institutional environmental guarantee for the effective implementation of internal audit. Internal audit is an important aspect of corporate governance structure. It provides the required information for corporate governance. The existence of reasonable internal audit is the inherent requirement of corporate governance.

Therefore, internal audit has a corporate governance role and plays an irreplaceable role in corporate governance.

\section{Conflicts of Interest}

The author declares no conflicts of interest regarding the publication of this paper.

\section{References}

[1] Li, B.S. (2015) On the Role of Internal Audit in Corporate Governance and Its Institutional Construction. Thesis, East China University of Political Science and Law, Shanghai.

[2] Qiang, H.D. (2015) Role Positioning and Function Reconstruction of Internal Audit in Corporate Governance. Thesis, Lanzhou Business School, Lanzhou.

[3] Lu, W.H. (2017) Research on Internal Audit Quality Control of XY Company. Thesis, Chongqing University of Technology, Chongqing. 
[4] Chen, H. (2016) Research on Internal Audit Outsourcing of SMEs in China. Thesis, Shaanxi University of Science and Technology, Xi'an.

[5] Peng, Y.M. (2016) Application of Governance Internal Audit in X Province Prison System Enterprises. Thesis, Hunan University, Changsha. 